\title{
Back pain in adolescents: prevalence and associated factors
}

\author{
Dor nas costas em adolescentes: prevalência e fatores associados
}

Mirna Namie Okamura1, Wilma Madeira², Moisés Goldbaum³ ${ }^{3}$ Chester Luiz Galvão Cesar ${ }^{1}$

DOI 10.5935/2595-0118.20190059

\section{ABSTRACT}

BACKGROUND AND OBJECTIVES: Back pain is one of the most common pain in humans. It impacts the health and quality of life and can be disabling. Diseases detected in adolescence and poorly managed may get worse in adulthood. The objective of this study is to estimate the prevalence, the associated factors and the characteristics of back pain in adolescents living in the city of São Paulo.

METHODS: A cross-sectional population-based study - Health Survey in São Paulo (2015) with 539 adolescents of both genders between 15 and 19 years old was used. The information was collected through home interviews and the participants were selected by probabilistic sampling. Frequencies, Chi-square test, and logistic regression analysis were used in this analysis. The level of significance was $5 \%$.

RESULTS: The estimated prevalence of back pain in adolescents in the city of São Paulo was 22.4\%. Back pain in adolescents had the following associated factors: dizziness (OR 3.1), common mental disorder (OR 2.4), insomnia (OR 2.6) and perform household chores (OR 1.8). To relieve the pain, $46.6 \%$ of adolescents do nothing, $17.3 \%$ use self-medication and $8.9 \%$ use prescribed medication.

CONCLUSION: Acknowledging back pain as a public health problem requires strategies that allow us to learn the origins, associated factors and coping strategies that may influence new ways of prioritizing and organizing healthcare.

Keywords: Adolescent, Back pain, Cross-sectional studies, Low back pain, Prevalence.

Mirna Namie Okamura - Dhttps://orcid.org/0000-0002-4547-7836;

Wilma Madeira - Dhttps://orcid.org/0000-0003-3885-7723;

Moisés Goldbaum - Dhttps://orcid.org/0000-0002-8049-7824;

Chester Luiz Galvão Cesar - (Dhttps://orcid.org/0000-0002-6999-1506.

1. Faculdade de Saúde Pública da Universidade de são Paulo, Departamento de Epidemiologia, São Paulo, SP, Brasil.

2. Hospital Alemão Oswaldo Cruz, Departamento de Filantropia, Săo Paulo, SP, Brasil.

3. Faculdade de Medicina da Universidade de São Paulo, Departamento de Medicina Preventiva, São Paulo, SP, Brasil.

Submitted on July 18, 2019.

Accepted for publication on September 17, 2019.

Conflict of interests: none - Sponsoring sources: O ISA-Capital 2015 foi financiado pela

Secretaria Municipal da Saúde de Sấo Paulo (Processo 0.235.936-0, de 2013).

Correspondence to

Rua Doutor Eduardo Amaro, 99 - apto 805 - Bairro Paraiso

04104-080 São Paulo, SP, Brasil.

E-mail:mirnaok@gmail.com mnokamura@prefeitura.sp.gov.br

(C) Sociedade Brasileira para o Estudo da Dor

\section{RESUMO}

JUSTIFICATIVA E OBJETIVOS: Dor nas costas é uma das dores mais comuns do ser humano. Afeta a saúde e a qualidade de vida, podendo ser incapacitante. Doenças detectadas na adolescência e mal manejadas podem se agravar na vida adulta. $\mathrm{O}$ objetivo deste estudo foi estimar a prevalência, fatores associados e características de dor nas costas em adolescentes da cidade de São Paulo.

MÉTODOS: Estudo transversal de base populacional - Inquérito de Saúde da Capital 2015, com 539 adolescentes de ambos os sexos e entre 15 e 19 anos. As informaçóes foram coletadas por meio de entrevistas domiciliares e os participantes foram selecionados a partir de amostragem probabilística. Frequências, teste do Qui-quadrado e análise de regressão logística foram utilizados na análise. O nível de significância adotado foi $5 \%$.

RESULTADOS: A prevalência estimada de dor nas costas em adolescentes da cidade de São Paulo foi de 22,4\%. Dor nas costas em adolescentes apresentou fatores associados com: tontura (OR $3,1)$, transtorno mental comum (OR 2,4), insônia (OR 2,6) e realizar atividades físicas domésticas (OR 1,8). Na busca por alívio da dor, 46,6\% dos adolescentes não fazem nada, 17,3\% buscam automedicação e $8,9 \%$ usam fármaco prescrito.

CONCLUSÃO: Entender a dor nas costas como um problema de saúde pública obriga a pensar em estratégias que permitam compreender origens, fatores associados e estratégias de enfrentamento que podem influenciar novas formas de priorizar e organizar a atenção à saúde.

Descritores: Adolescente, Dor lombar, Dor nas costas, Estudos transversais, Prevalência.

\section{INTRODUCTION}

Back pain is known as a major cause of disability ${ }^{1}$ in work and daily activities. Its origin, in part, refers to the use of the human body, which begins in childhood but starts to show its signs of use (or misuse) more intensely in adolescence. There is evidence that earlier intervention in this problem would bring more effective results in adulthood.

There are few studies on back pain, despite being a frequent health problem in the world population. Swain et al. ${ }^{2}$, in a systematic review of adolescents ( 9 to 17 years old), estimated the worldwide prevalence of back pain at $37 \%$. In local studies in Brazil, the prevalence found of back pain was in adults in the cities of Campinas-SP, $30.6 \%{ }^{3}$ and Pelotas-RS, $63.1 \%^{4}$, and in adolescents (10 to 17 years old), in Uruguaiana-RS, $16.1 \%{ }^{5}$. 
"Back pain" is a broad term, used colloquially ${ }^{3}$. Its importance is based on its high worldwide prevalence, its impact on people's quality of life, and its potential for disability to work. Given the breadth of the term, several studies prefer to treat only low back pain. In this study, the term "back pain" will be used, considering it as the grouping of the terms neck pain, upper back pain and low back pain.

This study aimed to estimate the prevalence, associated factors, and characteristics related to back pain in adolescents in the city of São Paulo in 2015.

\section{METHODS}

The data from the 2015 Health Survey of São Paulo were analyzed, a population-based cross-sectional study, with data collection conducted between September 2014 and December 2015. The 2015 Health Survey of São Paulo is a study consisting of a sample composed of people aged as of 12 years old, living in permanent private housing units, in the urban area of the city of São Paulo, which is the largest city and makes up the largest and most complex metropolitan region in Brazil. In this study, the stratified probabilistic sampling was used, with a two-stage draw: (1) census sectors; and (2) households ${ }^{6,7}$.

The prevalence refers to the population of the 2015 Health Survey of São Paulo study, which considered only the population living in urban areas, 9,349,890 inhabitants $^{6}$.

The study domains consisted of: (a) regions and (b) respondents in the 12-19-year old age group, 60 years old or older, and gender and age range of 20-59 years by gender (male and female). For the purpose of statistical inference, each individual in the sample was associated with a sample weight. The final weight was calculated according to three components: (1) design weight, which takes into account the sampling fractions of the two-stage draw; (2) non-response fit; and (3) post-stratification, which adjusts the distribution of the sample by gender, age group and region of residence, according to the population distribution in the municipality and according to the population estimate ${ }^{6}$.

For this study, 539 (98.4\%) respondents were selected, a sample composed of adolescents aged between 15 and 19 years, part of the age group of 12-19 years of the 2015 Health Survey of São Paulo. The 12-14-years old adolescents were removed from the sample because the questions related to the Self Report Questionnaire (SRQ), an integral part of 2015 Health Survey of São Paulo, were not applied to children under 15 years old.

The following dependent variable was considered:

1. back pain.

The following independent variables were considered:

2. Sociodemographic variables: gender, age, race/color, and education;

3. Variables related to health and lifestyle conditions: nutritional status ${ }^{8}$; smoking, alcohol use, and physical activity recommended by the World Health Organization (WHO). Physically active are those who have complied with the WHO recommendation to engage in light or moderate physical activity for at least 150 minutes per week or vigorous activity for at least 75 minutes per week? .
4. Variables related to chronic diseases and symptoms: all self-reported were considered and tested.

5. Emotional variables, those who answered 'yes' to eight or more questions from the 2015 Health Survey of São Paulo Block E, composed of questions from the Self Report Questionnaire 20 (SRQ20), an instrument with 20 questions for Common Mental Disorder (CMD) and can be used in primary care, validated by Gonçalves, Stein and Kapczinski ${ }^{10}$.

6. Characteristics of back pain: location, frequency, intensity, and attitudes for pain relief.

For the analysis of surveys based on complex designs, the survey module of the STATA14 program was used, which allowed the incorporation of the different weights.

The analysis was constructed by a logistic regression model to test the isolated association among the dependent variables (back pain) and each independent one, besides analyzing those that entered the final model.

All participants, or their guardians, signed Free Informed Consent Form (FICF) in which the research objectives and the information that would be requested were explained, ensuring the confidentiality of the information obtained. The research protocol was approved by the Ethics Committee of the Department of Epidemiology, School of Public Health, University of São Paulo - Opinion 1.420.473 (2015).

\section{Statistical analysis}

The prevalence between categorical variables was quantified by Pearson's chi-square test (p); those selected for the model were those with $\mathrm{p}<0.20$. In the final model, after selection tests, only variables with $\mathrm{p}<0.05$ remained in the model. Associations among variables were measured by the Odds Ratio (OR). The adjustment of the regression model was evaluated by the Archer and Lemeshow test ${ }^{11}$.

\section{RESULTS}

Of the 554 adolescents (aged 15-19 years) interviewed at the 2015 Health Survey of São Paulo, 539 (98.4\%), who responded to all the variables in this study, were identified as the studied population.

Of the 539 adolescents interviewed, 50.5\% were male and $49.5 \%$ female, so the proportion was quite approximate. The age distribution of this sample showed differences between 17.0 and $22.1 \%$, here also with approximate proportions. All other characterization variables of this population were homogeneous (Table 1).

When studying the population that identified as having problems related to back pain - which in this study includes low back, neck and upper back pain - it was possible to verify significant prevalence differences between females 28.1\% (95\% CI 22.6 - 34.2) and males 16.8\% (95\% CI 12.2 - 22.7), meaning that girls have almost twice as much back pain as boys. (Table 2) It was also possible to verify the existence of significant differences between self-perception of health. Those with 'not good' self-perception health were found to have a prevalence of $36.4 \%$ (95\% CI 28.6 - 45.0), while 19.0\% (95\% CI 14.9-23.9) had 
Table 1. Demographic profile of adolescents living in São Paulo city in 2015

\begin{tabular}{lcc}
\hline Demographic characterization & $\%$ total $(95 \% \mathrm{Cl})$ & $\mathrm{n}$ \\
\hline Gender & & \\
Male & $50.5(46.3-54.7)$ & 269 \\
$\quad$ Female & $49.5(45.3-53.7)$ & 270 \\
Age (years) & & \\
15 & $21.2(18.1-24.6)$ & 116 \\
16 & $17.0(13.6-21.0)$ & 91 \\
17 & $21.0(17.3-25.3)$ & 112 \\
18 & $18.7(15.4-22.6)$ & 104 \\
19 & $22.1(18.4-26.5)$ & 116 \\
Race/color & & \\
White & $44.8(39.7-50.1)$ & 230 \\
Black & $14.2(11.1-18.0)$ & 78 \\
Brown & $37.0(32.3-41.8)$ & 206 \\
Others & $4.0(2.4-6.4)$ & 22 \\
Education & & \\
Complete elementary school II & $33.3(29.4-37.3)$ & 180 \\
Complete elementary school I & $54.1(49.3-58.8)$ & 287 \\
Incomplete elementary school & $12.6(9.6-16.4)$ & 72 \\
\hline Cl = Confidence Interval. & &
\end{tabular}

Table 2. Adolescents with back pain: prevalence of demographic and lifestyle characterizations of residents in the city of São Paulo, 2015

\begin{tabular}{|c|c|c|}
\hline Variables & $\begin{array}{l}\% \text { Adolescents with } \\
\text { back pain }(95 \% \mathrm{Cl})\end{array}$ & P-value \\
\hline \multicolumn{3}{|l|}{ Demographic Characterization } \\
\hline Gender & & 0,0028 \\
\hline Male & $16.8(12.2-22.7)$ & \\
\hline Female & $28.1(22.6-34.2)$ & \\
\hline Age (years) & & 0.3329 \\
\hline 15 & $25.3(18.1-34.1)$ & \\
\hline 16 & $14.1(8.2-23.3)$ & \\
\hline 17 & $24.0(17.2-32.4)$ & \\
\hline 18 & $24.2(16.4-34.1)$ & \\
\hline 19 & $22.8(15.5-32.4)$ & \\
\hline Race/color & & 0.2178 \\
\hline White & $19.5(14.3-25.9)$ & \\
\hline Black & $28.0(19.0-39.2)$ & \\
\hline Brown & $24.7(19.1-31.2)$ & \\
\hline Others & $13.3(4.6-32.7)$ & \\
\hline Education & & 0.5989 \\
\hline Complete elementary school II & $22.8(16.4-30.8)$ & \\
\hline Complete elementary school I & $21.0(15.9-27.2)$ & \\
\hline Incomplete elementary school I & $27.3(18.4-40.3)$ & \\
\hline \multicolumn{3}{|l|}{ Lifestyle Characterization } \\
\hline Smoking & & 0.7368 \\
\hline Do not smoke & $22.7(18.6-27.2)$ & \\
\hline Currently smokes & $17.5(8.0-34.3)$ & \\
\hline Alcohol use & & 0.6195 \\
\hline Do not drink & $26.3(20.5-33.1)$ & \\
\hline Currently drinks & $33.1(20.0-49.4)$ & \\
\hline
\end{tabular}

self-perception 'good' health, as might be expected. What has drawn our attention was precisely $19.0 \%$ of adolescents who identified themselves with back pain problems, but with self-perception of 'good' health (Table 3).

Regarding the symptoms, diseases and other health problems, adolescents with back pain problems have a higher prevalence of associated factors such as headache 33.3\% (95\% CI $27.0-$ 40.3), anxiety 34.1\% (95\% CI $21.9-49.1$ ), sinusitis $34.7 \%$ (95\% CI 24.2 - 46.8), insomnia 46.4\% (95\% CI 36.0 - 57.1), CMD 49.0\% (95\% CI 38.6 - 59.4) and dizziness 49.9\% (95\% CI 37.3 -62.4). It meant that of the total of adolescents interviewed, at least one third reported comorbidities (Table 3). The estimated prevalence of back pain among adolescents in the city of São Paulo aged 15-19 years old was 22.4\% (95\% CI 18.4 - 26.9) (Table 4).

The characteristics of back pain for adolescents were related to greater identification with the location of pain in the lower back $42.9 \%$ (95\% CI $34.5-51.8)$. As for the frequency of pain, it was found that $58.2 \%$ reported having back pain at least twice a week $(41.0 \%$ have pain some days of the week, and $17.2 \%$ have every day). Regarding the intensity of the pain felt, $21.8 \%$

Table 3. Adolescents with back pain: prevalence of characterizations lifestyle and self-reported health problems in residents of the city of São Paulo, 2015

\begin{tabular}{|c|c|c|}
\hline Variables & $\begin{array}{l}\% \text { Adolescents with } \\
\text { back pain }(95 \% \mathrm{Cl})\end{array}$ & P-value \\
\hline \multicolumn{3}{|l|}{ Lifestyle Characterization } \\
\hline Nutritional status & & 0.0862 \\
\hline Normal and underweight & $20.3(15.8-25.6)$ & \\
\hline Overweight & $26.0(17.3-37.0)$ & \\
\hline Obese & $36.1(21.5-53.8)$ & \\
\hline \multicolumn{2}{|c|}{ Physical activity with leisure and transportation } & 0.7389 \\
\hline $\begin{array}{l}\text { Does not comply with the } \\
\text { recommendation }\end{array}$ & $22.8(18.3-28.1)$ & \\
\hline Complies with recommendation & $21.7(16.2-28.4)$ & \\
\hline Physical activity work & & 0.812 \\
\hline $\begin{array}{l}\text { Does not comply with the } \\
\text { recommendation }\end{array}$ & $22.5(18.2-27.4)$ & \\
\hline Complies with recommendation & $21.4(14.0-31.1)$ & \\
\hline Physical activity household chore & & $0.0019^{\star}$ \\
\hline $\begin{array}{l}\text { Does not comply with the } \\
\text { recommendation }\end{array}$ & $19.0(15.1-23.7)$ & \\
\hline Complies with recommendation & $32.9(24.6-42.3)$ & \\
\hline Health perception & & $0.0001^{*}$ \\
\hline 'Good' & $19.0(14.9-23.9)$ & \\
\hline 'Not good' & $36.4(28.6-45.0)$ & \\
\hline \multicolumn{3}{|l|}{ Characterization of health problems } \\
\hline Reported disease: rhinitis & $23.4(16.7-31.8)$ & 0.6200 \\
\hline Reported disease: sinusitis & $34.7(24.2-46.8)$ & $0.0107^{*}$ \\
\hline Reported disease: anxiety & $34.1(21.9-49.1)$ & $0.0374^{*}$ \\
\hline Reported problem: headache & $33.3(27.0-40.3)$ & $<0.0001^{*}$ \\
\hline Insomnia & $46.4(36.0-57.1)$ & $<0.0001^{*}$ \\
\hline Dizziness & $49.9(37.3-62.4)$ & $<0.0001^{*}$ \\
\hline Common Metal Disorder & $49.0(38.6-59.4)$ & $<0.0001^{\star}$ \\
\hline
\end{tabular}


reported having severe or unbearable pain, and $62.3 \%$ reported that this pain did not prevent them from performing their daily activities. Attitudes toward seeking back pain relief: drug use was reported by $26.5 \%$ (8.9\% prescription drug and $17.6 \%$ self-medication). Other reported non-pharmacological practices were: $11.2 \%$ do rest, $9.6 \%$ do physical activities, and $46.6 \%$ say they do nothing (Table 4).

From the univariate analysis, the following variables were selected: gender (Table 2), nutritional status and physical activities

Table 4. Prevalence and distribution of reported back pain characteristics of adolescents living in São Paulo city, 2015

\begin{tabular}{|c|c|}
\hline Prevalence & $\%(95 \% \mathrm{Cl})$ \\
\hline Back pain & $22.4(18.4-26.9)$ \\
\hline \multicolumn{2}{|l|}{ Distribution by location } \\
\hline Neck & $16.7(11.6-23.3)$ \\
\hline Upper back & $23.2(16.1-20.4)$ \\
\hline Low back & $42.9(34.5-51.8)$ \\
\hline Diffuse (1 or more locations) & $17.2(11.6-24.8)$ \\
\hline \multicolumn{2}{|l|}{ Frequency of back pain } \\
\hline Less than once a month & $14.7(8.5-24.2)$ \\
\hline A few times a month & $27.2(20.4-35.3)$ \\
\hline Some days of the week & $41.0(31.8-50.8)$ \\
\hline Every day & $17.2(11.7-24.4)$ \\
\hline \multicolumn{2}{|l|}{ Pain intensity } \\
\hline Weak & $38.6(30.0-48.0)$ \\
\hline Moderate & $39.6(30.7-49.2)$ \\
\hline Intense & $11.9(7.6-18.2)$ \\
\hline Unbearable & $9.9(5.4-17.5)$ \\
\hline \multicolumn{2}{|l|}{ Limits daily activities } \\
\hline Does not limit & $62.3(51.9-71.7)$ \\
\hline Little bit & $30.6(21.7-41.1)$ \\
\hline Very limited & $7.2(3.9-12.8)$ \\
\hline \multicolumn{2}{|l|}{ Attitudes for back pain relief } \\
\hline Does nothing & $46.6(35.9-57.6)$ \\
\hline Self-medication & $17.6(11.7-25.6)$ \\
\hline Prescription drug & $8.9(4.8-16.1)$ \\
\hline Rest & $11.2(6.6-18.4)$ \\
\hline Physical activity & $9.6(4.6-18.7)$ \\
\hline Massage & $4.0(1.8-9.0)$ \\
\hline Others & $2.1(0.5-8.1)$ \\
\hline
\end{tabular}

Table 5. Logistic regression analysis for adolescents with back pain living in the city of São Paulo in 2015

\begin{tabular}{lcrr}
\hline Variables & Gross OR & $\begin{array}{c}\text { Adjusted OR } \\
(95 \% \mathrm{Cl})^{*}\end{array}$ & P-value \\
\hline Dizziness & $4.5(2.5-8.1)$ & $3.1(1.6-5.9)$ & 0.001 \\
Common Metal Disorder & $4.3(2.7-7.1)$ & $2.4(1.4-4.4)$ & 0.002 \\
Insomnia & $3.7(2.3-6.1)$ & $2.6(1.6-4.3)$ & $<0.001$ \\
$\begin{array}{l}\text { Physical activity at } \\
\text { home }\end{array}$ & $2.1(1.3-3.3)$ & $1.8(1.1-2.9)$ & 0.027 \\
\hline & & & \\
\hline
\end{tabular}

related to household chore (Table 3), and characterization of health status: sinusitis, anxiety, headache, insomnia, dizziness and CMD (Table 3).

For the logistic regression model, the independent variables associated with back pain were: dizziness (OR 3.1), CMD (OR 2.4), insomnia (OR 2.6) and doing household chore-related physical activities (OR 1.8) (Table 5).

To check the predictive capacity of the logistic regression model, the Archer and Lemeshow test ${ }^{11}$ was applied, which indicated a $96.4 \%$ chance of an adolescent presenting back pain in the presence of these factors.

\section{DISCUSSION}

The study by O'Sullivan et al. ${ }^{12}$ recognized that back pain - low back, neck, and upper back pain - in adolescents is multifactorial and may be due to biological, psychological, physical, anatomical, lifestyle, and comorbidities.

Swain et al. ${ }^{2}$, in a study with data from 28 countries, estimated the worldwide prevalence of back pain in adolescents (9 to 17 years old) at 37\%, with the lowest prevalence in Poland (27.7\%) and the highest prevalence in the Czech Republic (50.5\%). In this study, the estimated prevalence of back pain in adolescents (15 to 19 years) in the city of São Paulo, Brazil, is 22.4\% (95\% CI 18.4 - 26.9), a result below other countries.

The association between CMD and back pain has been found in different studies ${ }^{12,13}$. This study also identified a significant association between CMD and back pain in adolescents from the city of São Paulo (OR 2.4, 95\% CI 1.4 - 4.4). Viana et al. ${ }^{14}$ concluded in their study that individuals with CMD are at higher risk of developing back pain, which may mean that the experience of physical and emotional pain in adolescents may not be independent, emphasizing the importance of detecting such associations.

Dizziness as the primary association with back pain in adolescents from the city of Sáo Paulo has not been presented as an associated factor when studying back pain, although it was found in this study. In a survey, Janssens et al. ${ }^{15}$ published on American and Dutch adolescents, in which they identified an association between pubertal delay and back pain, excessive tiredness and dizziness. In this study, the association appears simultaneously, but it is not possible to confirm the direct association.

Insomnia is an inability to sleep properly, therefore a symptom of poor sleep quality. Auvinen et al. ${ }^{16}$ and Dey, Jorm, and Mackinnon ${ }^{17}$ found an association between poor sleep quality and back pain. In these studies, there is a significant association between back pain and insomnia (OR 2.6 - 95\% CI 1.6 - 4.3). It is difficult to identify the origin of this association; if back pain leads to poor sleep quality (insomnia), or if insomnia contributes to back pain. The health problem related to back pain refers in part to the use and disuse of the human body. The association between back pain in adolescents from the city of São Paulo and the performance of domestic physical activity was identified (OR 1.8 - 95\% CI 1.1 - 2.9). However, the classification related to the Physical Activity block of 2015 Health Survey of São Paulo presented only results related to compliance or not with WHO recommendations ${ }^{9}$, which became an important limitation of this study, since 
such classification does not have a range that allows recognizing the excess of adolescents in relation to the performance of such physical activities.-

As the study refers to adolescents, a contemporary factor of common knowledge related to intense physical activity in the household chores, identified with frequent and inappropriate body postures, is the excessive use of new technologies in this age group. Sjolie ${ }^{18}$ demonstrated an association between excessive leisure activity and back pain. Noll et al. ${ }^{19}$, in a study with adolescents, identified an association between different postures and body uses (computer use, daily time spent watching television, studying in bed, sitting posture to write and backpacking) with back pain. In this study, it was not possible to identify such associations since classifications related to the intense and/or inappropriate use of technologies are not part of the data available in 2015 Health Survey of São Paulo.

Finally, Hestbaek et al. ${ }^{20}$ showed that there was a correlation between low back pain diagnosed in childhood/adolescence and the permanence of the problem in adulthood, and suggest that the focus of prevention, treatment, and research related to back pain problems should be in children and adolescents. The results of this study support this conclusion.

In addition, it has been found that back pain is usually treated with painkillers, but there are other treatments that include physical therapy, physical exercise, and spinal manipulation ${ }^{1}$. Self-medication has been considered a significant public health problem. Pardo et al. ${ }^{21}$ relate self-medication as the primary search for relief to face pain-related issues. Arrais et al. ${ }^{22}$ estimate the prevalence of self-medication in Brazil at $16.1 \%$. In this study, self-medication used to seek back pain relief was reported by $17.6 \%$ of adolescents.

Shipton ${ }^{23}$ warns that non-pharmacological treatment to address back pain is important because it improves body function and decreases disability. In this study, approximately a quarter (24.8\%) of adolescents in the city of São Paulo who reported having back pain reported using other non-pharmacological mechanisms to relieve it, such as massage (4.0\%), activity physical $(9.6 \%)$, and rest $(11.2 \%)$.

\section{CONCLUSION}

Understanding back pain as a public health problem requires us to think of strategies that allow us to understand origins, associated factors, and coping strategies that may influence new ways of prioritizing and organizing health care in the Unified Health System (SUS) and in complementary health services in the country.

Thus, the four factors (dizziness, common metal disorder, insomnia, and domestic physical activity) associated with back pain should be considered for diagnosis, treatment, and proper clinical management.

Finally, it is important to highlight that diseases detected and managed improperly in adolescence can worsen in adulthood.

\section{REFERENCES}

1. Duthey B. Low Back Pain. Geneve: WHO; 2013. [cited 2018 Oct 20]. Available from: http://www.who.int/medicines/areas/priority_medicines/BP6_24LBP.pdf.

2. Swain MS, Henschke N, Kamper SJ, Gobina I, Ottová-Jordan V, Maher CG. An international survey of pain in adolescents. BMC Public Health. 2014;14:447.

3. Iguti AM, Bastos TF, Barros MB. [Back pain in adults: a population-based study in Campinas, São Paulo State, Brazil]. Cad Saude Publica. 2015;31(12):2546-58. Portuguese.

4. Ferreira GD, Silva MC, Rombaldi AJ, Wrege ED, Siqueira FV, Hallal PC. Prevalência de dor nas costas e fatores associados em adultos do Sul do Brasil: estudo de base populacional. Rev Bras Fisioter. 2011;15(1):31-6.

5. Graup S, Araújo Bergmann ML, Bergmann GG. Prevalence of nonspecific lumbar pain and associated factors among adolescents in Uruguaiana, state of Rio Grande do Sul. Rev Bras Ortop. 2014;49(6):661-7.

6. Săo Paulo (SP) Secretaria Municipal da Saúde. Coordenaçấo de Epidemiologia e Informaçấo - CEInfo. Boletim ISA Capital 2015, nº 0, 2017: Aspectos metodológicos e produçẫo de análises. São Paulo: CEInfo; 2017, 32 p. [cited 2018 Oct 28]. Available from: http://www.prefeitura.sp.gov.br/cidade/secretarias/upload/saude/arquivos/publicacoes/ISA_2015_MA.pdf.

7. São Paulo (SP). Secretaria Municipal da Saúde. Coordenação de Epidemiologia e In formação - CEInfo. ISA Capital - Inquérito de Saúde no Município de São Paulo, 2014. Săo Paulo: CEInfo; 2014. [cited 2018 Oct 28]. Available from: https://www. prefeitura.sp.gov.br/cidade/secretarias/upload/saude/arquivos/isacapitalsp/questionario isacapital-completo.pdf.

8. São Paulo (SP). Secretaria Municipal da Saúde. Coordenação de Epidemiologia e Informaçâo - CEInfo. Boletim ISA Capital 2015, no 6, 2017: Estado nutricional da populaçấo da cidade de São Paulo. São Paulo: CEInfo; 2017, 83 p. [cited 2018 Nov 3]. Available from: http://www.prefeitura.sp.gov.br/cidade/secretarias/upload/saude/ arquivos/publicacoes/ISA_2015_EN.pdf.

9. São Paulo (SP). Secretaria Municipal da Saúde. Coordenação de Epidemiologia e Informação - CEInfo. Boletim ISA Capital 2015, no 18, 2018: Atividade física na cidade de São Paulo. SãoPaulo: CEInfo; 2018, 38 p. [cited 2018 Nov 3]. Available from: http://www.prefeitura.sp.gov.br/cidade/secretarias/upload/saude/arquivos/publicacoes/ISA_2015_AF.pdf.

10. Gonçalves DM, Stein AT, Kapczinski F. [Performance of the Self-Reporting Questionnaire as a psychiatric screening questionnaire: a comparative study with Structured Clinical Interview for DSM-IV-TR]. Cad Saude Publica. 2008;24(2):380-90. Portuguese.

11. Archer KJ, Lemeshow S. Goodness-of-fit test for a logistic regression model fitted using survey sample data. Stata J. 2006;6(1):97-105.

12. O'Sullivan P, Smith A, Beales D, Straker L. Understanding adolescent low back pain from a multidimensional perspective: implications for management. J Orthop Sport Phys Ther. 2017;47(10):741-51.

13. Rees CS, Smith AJ, O'Sullivan PB, Kendall GE, Straker LM. Back and neck pain are related to mental health problems in adolescence. BMC Public Health. 2011;11:382-90.

14. Viana MC, Lim CCW, Pereira FG, Aguillar-Gaxiola, Alonso J, Bruffaerts R, et al. Previous mental disorders and subsequent onset of chronic back or neck pain: findings from 19 countries. J Pain. 2018;19(1):99-110

15. Janssens KAM, Rosmalen JGM, Ormel J, Verhulst FC, Hunfeld JAM, Mancl LA, et al. Pubertal status predicts back pain, overtiredness, and dizziness in American and Dutch adolescents. Pediatrics. 2011;128(3):553-9.

16. Auvinen JP, Tammelin TH, Taimela SP, Zitting PJ, Järvelin MR, Taanila AM, et al. Is insufficient quantity and quality of sleep a risk factor for neck, shoulder and low back pain? A longitudinal study among adolescents. Eur Spine J. 2010;19(4):641-9.

17. Dey M, Jorm AF, Mackinnon AJ. Cross-sectional time trends in psychological and somatic health complaints among adolescents: a structural equation modelling analysis of 'Health Behaviour in School-aged Children' data from Switzerland. Soc Psychiatry Psychiatr Epidemiol. 2015;50(8):1189-98.

18. Sjolie AN. Associations between activities and low back pain in adolescents. Scand J Med Sci Sport. 2004;14(6):352-9.

19. Noll M, Candotti CT, Rosa BN, Loss JF. Back pain prevalence and associated factors in children and adolescents: an epidemiological population study. Rev Saude Publica. 2016;50. pii: S0034-89102016000100219.

20. Hestbaek L, Leboeuf-Yde C, Kyvik KO, Manniche C. The course of low back pain from adolescence to adulthood: eight-year follow-up of 9600 twins. Spine. 2006;31(4):468-72.

21. Pardo IM, Jozala DR, Carioca AL, Nascimento SR, Santucci VC. Automedicação: prática frequente na adolescência? Estudo em uma amostra de estudantes do ensino médio de Sorocaba. Rev Fac Cienc Med Sorocaba. 2013;15(2):11-5.

22. Arrais PS, Fernandes ME, Pizzol TD, Ramos LR, Mengue SS, Luiza VL, et al. Prevalence of self-medication in Brazil and associated factors. Rev Saude Publica. 2016; 50(Suppl 2):13s. English, Portuguese.

23. Shipton EA. Physical therapy approaches in the treatment of low back pain. Pain Ther 2018;7(2):127-37 